THE CONCEPTION OF GOD IN THE LATER ROYCE 


\title{
THE CONCEPTION OF GOD IN THE LATER ROYCE
}

\author{
by \\ EDWARD A. JARVIS, S.J.
}

With a foreword

by

Frank M. OPPENheIM S.J.

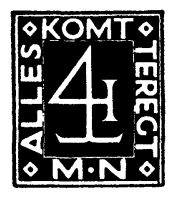

MARTINUS NIJHOFF / THE HAGUE / 1975 
To Donald and Idella Gallagher

(C) 1975 by Martinus Nijhoff, The Hague, Netherlands All rights reserved, including the right to translate or to reproduce this book or parts thereof in any form ISBN-13: 978-90-247-1713-2 e-ISBN-13: 978-94-010-1659-9 DOI: 10.1007/978-94-010-1659-9 


\section{CONTENTS}

Foreword . . . . . . . . . . . . . .

Preface . . . . . . . . . . . . . . $\mathrm{xIX}$

\section{THE EARLY THOUGHT OF ROYCE}

Introduction . . . . . . . . . . . . . 1

1. Moral Theory . . . . . . . . . . . . 2

2. Empirical Theism . . . . . . . . . 5

3. Postulates. The Right to Believe . . . . . . . 7

4. Idealism as an Hypothesis Based on Postulates . . 11

5. Skepticism and the Possibility of Error . . . . 15

6. Common Sense and the Problem of Error . . . . 17

7. Solution and Conclusion to Absolute Idealism . . . 21

8. Absolute Idealism and the Nature of Error . . . 24

9. The Problem of Evil . . . . . . . . . 27

10. The Conception of God. Critique . . . . . . 30

II. THE MIDDLE THOUGHT OF ROYCE

1. Transition to "The World and the Individual" . . . 35

2. "The World and the Individual": Introduction . . . 41

3. Realism . . . . . . . . . . . 44

4. Mysticism . . . . . . . . . . . 47

5. Critical Rationalism . . . . . . . . . 49

6. The Internal and External Meaning of Ideas . . . 52

7. The Fourth Conception of Being . . . . . . 58

8. The Proof of God's Existence . . . . . . . 61

9. The One, the Many, and the Infinite . . . . . 67

10. The Temporal and the Eternal . . . . . . 73 
11. The Moral Order and the Problem of Evil . . . . 79

12. Immortality . . . . . . . . . . 82

13. The Conception of God. Summary . . . . . 84

III. THE LATER THEORY OF COMMUNITY

1. Transition to "The Problem of Christianity" . . . 91

2. "The Problem of Christianity": Introduction . . . . 97

3. The Moral Burden of the Individual . . . . . 101

4. Guilt and Atonement . . . . . . . . 106

5. The Beloved Community . . . . . . . . . 111

6. The Community and the Time-Process . . . . . 115

7. The Body and Its Members . . . . . . . . 118

8. The Nature of Interpretation . . . . . . . . 124

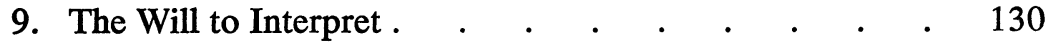

\section{THE LATER CONCEPTION OF GOD}

1. The World of Interpretation . . . . . . . 140

2. The Theoretical and the Practical . . . . . . 148

3. Peirce's "Neglected Argument" . . . . . . 156

4. The Conception of God . . . . . . . . . . . 162

5. Elements in Royce's Later Conception of God Which are Similar to and Continuous with Earlier Conceptions . . 169

6. Elements in Royce's Later Conception of God Which are Different from His Earlier Conceptions. Summary . . 173

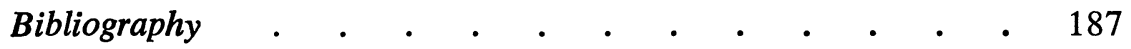

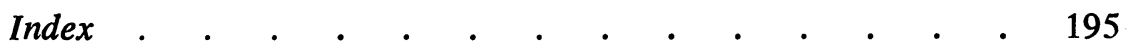




\section{FOREWORD}

Dr. Jarvis kindly invited me to undertake this Foreword. According to his suggestion, I here intend to complement his work by creating a context for it. To do so, prior notice of a common misrepresentation of Royce and of his contemporary relevance seems needed, before briefly sketching his biography and interest in religion. Finally, to orient the reader to the present study, I will point out Royce's main works and the spirit of the man.

In the year 2150 A.D., what will people be saying about Harvard? If the reported prediction of a self-effacing William James comes true, the common answer will be, "Harvard? Oh, that's the place where Royce taught." And yet, now that almost a century has passed since Royce began teaching at Harvard, most Americans do not recognize the name "Josiah Royce." Of those who do, few know him as a significant American philosopher of community. And of these few, far fewer recall either that religious problems first drove Royce to philosophy or that he said such problems "of all human interests, deserve our best efforts and our utmost loyalty." 1 Little wonder, then, that when Americans survey our "classic" philosophers-Peirce, James, Royce, Santayana, Dewey, Whitehead-few of them respond to Royce as the most explicitly and persistently religious philosopher of them all.

Fortunately, however, popularity contests do not accurately weigh the merit of a philosopher. For that depends on his perspective, penetration, and perdurance in enriching human life. William James may have aptly estimated that 250 years would be needed before Royce's stature as a thinker could be appraised accurately. Do not the Japanese have to travel many miles from Fujiyama before it stands out clearly and majestically on their horizon? And yet, even now with less than a hundred years

\footnotetext{
${ }^{1}$ Josiah Royce, The Religious Aspect of Philosophy (Boston: Houghton Mifflin and Co., 1885), v.
} 
perspective on Royce, some already find the emerging genius of this philosopher fascinating. Scholars are beginning to recognize that Royce's mind was amazingly complex and subtle. His interests and researches were labyrinthine. Yet in his maturity (1912-1916) he achieved a profound simplicity. What sort of man, then, was this Royce? And what sort of life was his?

Josiah Royce (1855-1916) was born in the gold-mining village of Grass Valley, California. His parents were '49ers, tested by poverty and the disorder of a people scarcely ready for statehood. His mother, Sarah Eleanor Royce, wrote a diary ${ }^{2}$ of their trek to California and the family's later meanderings there. She was the first teacher of young "Josie" in cultivated living, religion, morals, and philosophy. In 1866 the Royces moved to San Francisco for more education. Here the lad encountered Lincoln Grammar School's one thousand boys. As a horde they impressed on him lessons that his earlier, almost entirely feminine environment could never have done. ${ }^{3}$ His educational staircase ascended through Boys High School, nascent University of California, a year abroad in Germany, and doctoral studies at The Johns Hopkins University. After a four-year instructorship in English at Berkeley, Royce risked all by moving his young wife and child cross-country to Harvard to accept a one-year offer of teaching philosophy. Gradually he made his mark. Harvard offered more permanent commitments. And eventually Royce taught philosophy from 1882 to 1916, almost always at Harvard. The external events of Royce's life, then, were simple and non-spectacular. Yet the internal turns and growth in his mind will require volumes of biography to describe, correlate, and evaluate carefully.

Lacking such a biography, we are almost left at the mercy of classifiers and popularizers. Many of these misrepresent Royce when they picture him primarily as a purveyor of German idealism. This legend, handed down the decades since 1900, misleads readers on many counts. First, Royce regarded himself as natively American. His originality was American. And the thinker from whom he eventually derived most was the American philosopher, C. S. Peirce. Secondly, the legend disregards Royce's tenacious spirit of "being a Californian." He interpreted this as being "earnest, independent, and reverent," or, on another occasion, as

${ }^{2}$ Subsequently published as A Frontier Lady, R. H. Gabriel, ed. (New Haven: Yale University Press, 1932).

${ }^{3}$ His father, Josiah, Sr., was often absent with the miners, especially during young Josiah's first eleven years in Grass Valley. 
thinking "reverently, fearlessly, and honestly." ${ }^{4}$ Then, too, the German labelling omits the English stamp on Royce, a counterbalance far more needed in fairness. For his family lineage was purely British. His first philosophical readings were in Mill, Spencer, and Hamilton. Later he closely studied Hodgson, Bradley, and Russell. More misleading still, the label of German idealism is often attached to Royce with the connotations of an Hegelianism. But this overlooks Royce's acknowledgement of his far greater debts to Fichte, Schopenhauer, and especially Kant.

Yet one thing misleads most. For to classify Royce primarily as a German type idealist is to suppress any mention of the originality that was his. Royce initiated a distinctive theory of individuality, discovered five conditions for the consciousness of genuine community, and transcended philosophical traditions by transforming Peirce's triadic theory of interpretative knowing into a metaphysics of community. His originality also appeared in his synthesis of a three-factored truth-theory that exposed how narrow a base James had used for his pragmatic theory of truth. Royce was also authentic enough to upbraid certain self-styled "realists" and later naturalists for being "soft" philosophically. For by their choice of philosophical method they avoided investigating life's perennially difficult problems-such as life itself, death, evil, and the meaning of our universe, or the mysteries of our good, goal and God. Alert to a misleading old label, then, we can search more freely to find Royce as he was-an original thinker and an American.

And then, what can Royce mean for us? To attend sympathetically and discerningly to Royce is generally to undergo a growth experience. For Royce needs neither an apologist nor someone to indicate his "relevance" today. For simply to avoid Royce's mind, or to misunderstand him, is to trap oneself in self-impoverishing consequences. Others, however, meet Royce's mind accurately and experience both enrichment and his present significance.

For the latter group, Royce's seminal suggestions about community consciousness pave the way towards sharing sound expectations for communal living. If amid remembered alienations and those breaking out afresh we are to achieve and enhance community cooperation, then Royce's emphasis on the prerequisite moral healing of finite selves and their re-dedication to deeds decisive for genuine community life is indispensable. And currently, since people are called to yet more

4 Josiah Royce, Fugitive Essays, J. Loewenberg, ed. (Cambridge, Mass.: Harvard University Press, 1920), 7; and The Religious Aspect of Philosophy, 5. 
careful dialogue for developing communities, the mature Royce's hints about the social arts of interpretation become more pertinent.

American problems still with us won Royce's attention. Today some still assume that what makes America strong is a certain highly-praised type of individualism. According to it, a person invests his talents and energies where he wishes, but as far as possible avoids articulating his responsibilities to others so his "free scope of action" will not be curtailed. In practice, this allows him to "get away with as much as he can," without being liable to the charge of violating acknowledged responsibilities. Against such an individualism Royce launched a sharp and much needed attack.

We Americans also find ourselves, like most earth inhabitants, variously prodded towards adopting a more unified view of our earth and its problems. Associated with this is the felt danger of falling into one uniform world-culture, promoted by mass-media and pushers of consumerism. Such a culture would be even more flat and monotonous than that which marks "auto-strip, U.S.A." Against such a captivating culture, Royce advocated wise distinctive provincialisms which create variety of riches and counterbalancing strengths within our emerging world culture.

Significant for our world, too, is the way Royce valued and refined his conception of God. His treasuring of it challenges American's widespread indifference to religion. For instance, three out of four American collegians polled in 1974 regarded religion as unimportant for human life. Were he taking that poll, Royce would enjoy critically testing their responses. Yet he would first agree how correct they are if the human life whose importance they estimate is only a one-dimensional search for consumer-satisfaction. For a view of life based mainly on being a satisfied consumer is soured by even a slightly adequate conception of God. With his passionate will for more truth, however, Royce could not stomach such an inadequate view. For he knew the human self is inescapably more than a consumer, and that "of all human interests, [religious problems] deserve our best efforts and our utmost loyalty."

It can be risky to move from a general awareness of Royce's relevance for our age to a direct study of how his conception of God developed. For the overall balancing context has to be kept in view. Which other aspects of Royce's life, then, need to be noticed as we begin narrowing the focus to Royce's philosophy of religion, or even more precisely, to his conception of God? 
Reconstructing an evening in 1892 may help. We can picture Royce the family man sitting in the music room of his Cambridge home at 103 Irving Street. Katharine, his wife, plays the piano, and at her side so does Chris, their ten-year-old eldest. Meanwhile, their youngest, Stephen, sits on the floor as three-year-olds do, beating out the melody on the knees of his six-year-old brother, Ned. Absorbing the entire scene is cigar-smoking Josiah, who intermittently focuses with the interest both of a father and of a psychologist on bustling Stephen's gestures and attempted sing-along. The Royces knew many years of family joys and hopes before the shadow of mental imbalance touched their brilliant Christopher a decade later and sowed anxiety into the whole family.

After the family hour, Royce retires to his study. There we can vicariously experience his interest in ethics, metaphysics, and logic. On his desk we notice the half dozen books in ethics which he has just finished examining for his annual published review. His shelves are lined with tomes of metaphysics from Aristotle and Plato, in their Greek originals, through Kant, Hegel, Schelling, Hume, and Mill, down to the latest metaphysical works. True, in a decade or two these shelves will groan with boxes of his logical notebooks and researches. But in these nineties, the periodicals on his shelves and the many papers witness to his interest in psychology, to the origin of social consciousness, to imitative factors in early child psychology, and to hypnotism, hallucinations, and presentiments-all part of his work in the Society for Psychical Research.

A surprising amount of shelf and file space is taken by Royce's data boxes, notebooks, and background papers-all part of his continuing study of the California question. He was deeply concerned. Did the American conquest there in 1846 amount to an immoral take-over of California from the Mexicans? Although today many overlook Royce's role as an historian of California and as an historian of philosophy, he contributed significantly to both. In the latter field, he has some claim to the title of father of the organized study of the history of philosophy in America. As we browse around his shelves, if we happen upon his only published novel, The Feud of Oakfield Creek, predictably Royce will wryly smile-and at something more than his failure as a novelist. For he feels the paradoxical tension between wanting to aid as many as possible to moral insight and yet knowing his field of theoretical ethics does not touch people so powerfully as does a well-executed novel. 
But to view him in his music room and study is not to see him operate in public. His public was that of a professor of philosophy. $\mathrm{He}$ invested almost forty years in the classrooms of Berkeley and especially of Harvard. Moving beyond this, he delivered well over five hundred public lectures at university podia and theaters across the land. In his own lecture room, he encountered the upcoming generations. Some he found indifferent, some hostile, some enthusiastic towards the philosophy he proposed and sifted with them.

Summing up all these signs marking Royce's life, one begins to grasp how wide the scope of his interests and how massive the investment of his energies in fields other than religion. Even though he never changed the highest estimate he early placed on religious problems, what tends to overwhelm is the quality and quantity of effort Royce invested in other fields-in ethics, logic, metaphysics, history, literary criticism, psychology, and mathematics. To experience this, one needs simply to enter the Harvard Archives and skim through Royce's extant writings. For a feeling of "massiveness" generally steals upon the alert person who weaves his way through the ninety-eight folio volumes of Royce's bound MSS and then peruses the fourteen large boxes of his remaining papers and notebooks. Such an experience underscores the broad context of other interests which Royce cultivated besides the religious one that first drove him to philosophy.

We have toured Royce's richly variegated garden and come to the central "tree of life," his religious interest. Since Dr. Jarvis carefully focuses on only some ingredients in that interest, a brief mental stroll around this tree may let the reader better situate himself. The aim of our stroll, then, is simply to notice the fruits produced by Royce's religious interest and to observe how he embodied it in his own life.

If one peruses a bibliography of Royce's works, he frequently encounters titles about God or religion. Royce's collegian writings include a significant article on the Holy Grail and his B. A. thesis on Greek theology. If one turns to Royce's later religious articles and selects just a few high points, he will find such titles as "Browning's Theism," "Meister Eckhart," "The Problem of Natural Religion," "What Should be the Attitude of Teachers of Philosophy of Religion?" "George Fox, the Mystic," and Royce's "Monotheism" article in Hastings' Encyclopedia. If one focuses on Royce's main works in religion, he discovers the following impressive series of titles during three decades: The Religious Aspect of Philosophy (1885), The Conception of God (1895, 1897), The World and the Individual (1899, 1901), The Philosophy of Loyalty 
(1907), then Royce's late study of religious experience, The Sources of Religious Insight (1912), and his application of its findings to one world religion in his deservedly well-known The Problem of Christianity (1913). Royce's religious interest was at least prolific and persistent. By contrast, John Dewey's religious interest permitted itself only one well-known expression in his brief but influential work, A Common Faith. Dewey's reticence leaves our secularized attitudes less disturbed. But if frequency and depth of critical articulation help develop and refine one's religious interest, then Royce's series of books and articles down the decades witnesses to a superbly adroit and cultivated interest in religion, which deservedly wins our attention.

But our list of titles might merely document Royce's perduring philosophical interest in religion and his scholarly attempts to refine his notion of God. For balance, we need to examine some slices of his personal behavior to find the authentic quality of Royce's not merely philosophical, but personal interest in religion.

Royce first learned of God from his parents in their Grass Valley home. They saturated him with family Bible readings and church-goings. "Josie" soon dived boldly into the Apocalypse as the start of his reading career. And shortly, on his walks through the woods, he would meditate. Later, when sharing his religious queries with a minister, the latter delighted the lad by assuring him that God wants people to doubt His existence if it leads them to know Him better. As a collegian, why did Royce draft a detailed chronology of the origins of Christianity? And in his B. A. thesis, why did he examine the ingredients in the Greeks' conception of the divine? Noteworthy is his finding of emotive as well as cognitive traits in that conception. The Greeks portrayed the divine as august or reverend because for them the divine radiated the "fearful" or the "morally good" or the "nobly beautiful," or some blend of these qualities. Although Royce's conception of God would undergo transformations through later decades, this cognitional-emotive sense of "god-for-us-people" persisted.

His notion was clearly allied to the West's traditional conception of God which he derived from three fairly distinct sources. From the Greeks came the divine traits of unique, all-knowing, Orderer of the world. From the Hebrews came purposive moral Will. From Asiatic Indians came much "negative theology"-God is NOT like anything we know.

As an Instructor at Berkeley, during his sceptical period (1875-1882), Royce once sat contemplating the Golden Gate. In this meditation, 
he found the divine in the felt Presence within a lovely yet mysterious Nature. He called it "World Spirit" and viewed it as pervasively present rather than as some far distant deity unrelated to people. ${ }^{5}$ Soon in his 1885 Religious Aspect of Philosophy, he "demonstrated" an all-seeing truth-constituting Judge. A few years later, however, when sailing off to Australia to relieve an overworked brain, Royce found his conception of God mellowing. This 1888 God became less the terminus of a logical inference and much more a concrete Living Presence, surcharged with Life and authoring Life. He was an Individual Will that embodies Itself in the life and history of the whole cosmos, the Life Source of all suns and Milky Ways. In sum, perhaps Royce's conception of God in his B. A. thesis may have worked dialectically enough upon his 1885 heavily intellectualistic conception of God as all-seeing Judge to allow his 1897 conception to become progressively more balanced with the traits of immanent Author of life and of Individuality.

After the turn of the century, which events in Royce's life highlighted the quality of his religious interest? In 1908, he confessed to being promptly and strongly impressed by his encounter with C. S. Peirce's "A Neglected Argument for the Reality of God" in the Hibbert Journal. In 1909, his lecture, "What is Vital in Christianity?" announced an interest into which Royce would invest the best efforts of his final years. In October, 1910, Royce confided to Professor Palmer that he was taking a fresh look at St. Paul's doctrine "on the spiritual gifts." A few weeks later he recorded that he saw his vocation to be helping others live "in the unity of the Spirit." During Spring, 1911, he helped conduct a course for Harvard seniors at the Phillips Brooks House on "Some Present Day Religious Problems." The Harvard Crimson called attention to one of these, entitled "The Personal Meaning and Value of the Idea of God." All these expressions of his religious interest pushed steadily to their climax in Royce's Sources of Religious Insight (1912) and on into The Problem of Christianity (1913). Taken together, these signs evidence in Royce a religious interest that was radically personal and also authentically philosophical.

We saw that as early as 1879 Royce in his "Meditation before the Gate" had committed himself to consider reality "earnestly, reverently, and independently." Did not this choice of philosophical style already signal a certain response to life and its Author? One may wonder how Royce's religious interest was influenced by his habit of solitary medi-

${ }^{5}$ Fugitive Essays, 6. 
tation. For instance, what was happening to Royce's conception of God when as a young man he hiked alone on a path up the Coastal Range or climbed Mt. Diablo? Why did he enjoy camping in Yosemite or walking in the woods during those summer school sessions up at Thomas Davidson's camp in the Adirondacks? Why did he sit alone for long hours on the rear deck of a Caribbean fruit-steamer-a philosopher wrapped in silent musement. Certainly many of these cruising hours were dedicated to logical excogitations. But it is fitting to assume that sometimes he was here already doing what his Assistant, the late William F. Kernan, witnessed Royce engaged in during his final weeks in 1916. Then he spent hours of quiet meditative musings, filled with a sense of "being with" something (or Someone?) greater than himself, according to Kernan. Twenty years earlier he would only have read Scripture if well armed in advance with the best scholarly tools. But in his final years he mentioned that he now read Scripture with the greatest childlike simplicity he could achieve. Meanwhile, many of his Cambridge neighbors referred to him as "the mystic of Irving Street." He had spoken of each one's Internal Meaning that continuously reaches out ever further to the Other lying beyond his every effort and finite action. Accordingly, was Royce's personal religious interest the most central core of his own Internal Meaning?

In his relation to Christianity, the elderly Royce found his years of fidelity to this religious interest drove him to view and proclaim himself in the role of John the Baptist. ${ }^{6}$ Many, on first hearing it, are puzzled by this seemingly bizarre self-identification. Yet on investigation, I find Royce's claim most significant. It is a fitting contribution to the philosophy of religion since it comes from an American in the Evangelical tradition. Even more, Royce's choice is a wise one since it achieves three things. It frees him from entrapment in the usual categories. It transforms him into a sign-function of genuine loyalty. It alerts him to search for God in all events. A brief expansion of these claims seems needed.

First, Royce's John the Baptist role frees him from the usual postures towards Christianity-that of the apologist, or the hostile critic, or the indifferent. At least a blight touches these traditional stances. Over and beyond his unneeded defensive stance, the Christian apologist usually saddles himself with the non-divine burden of dogmatic formulations, scriptural genres, and traditions. The critic who is fundamentally hostile

- Josiah Royce, The Problem of Christianity, II, 385-386. 
to Christianity reveals he has not appreciatively experienced the reality of its central life and saving power, and by his destructive attack risks contravening Gamaliel's advice. ${ }^{7}$ Those who find Christianity irrelevant and are indifferent to it "are generally unaware of what salvation through loyalty signifies." 8

Second, the Baptizer posture of Royce carries him beyond his earlier dyadic stance of a simple "seeker of truth" It operatively places him in a triadic process wherein he also functions as a "maker of an interpretation" in a community. Much as the historic John the Baptist functioned as witness between Jesus and potential Christians, so Royce chose to operate as "witness" or "herald." And for Royce, any "christian"- that is, anyone authenticated by his loyal concern for allis called to this kind of witnessing. Royce also saw the whole loyal Community similarly called to herald the divine Spirit to an as yet unbelieving humanity.

Third and lastly, Royce, as this kind of heralding witness, accepts God's initiative in our midst as given, as did the historic Baptist. Through His Spirit and Word, the King of the Kingdom operates in and out of human hearts, making "the Kingdom come." In the context of this divine operation, the human witness points to it. He signals that it is "still at hand." He does this precisely in the way that each temporal event is a "pointer" in its own way and according to its own special significance. That is, says, Royce, like each happening, the herald exists as "a prophecy of the triumph of the spirit, and a revelation of the everlasting nearness of the insight that interprets, and of the victory which overcomes the world." 10 This offers no long-range vision of universal history. Rather, for those who attend he offers enough light to guide them simply on their next step. By his discerningly loyal decision, the herald makes enough light be "at hand" that he and others can search for the divine in their next step, much along the lines of Newman with his thematic prayer, "Lead, kindly light." 11

7 Acts 5:34-42.

8 The Problem of Christianity, II, 390.

- By his supra-denominational choice of the Baptist posture, Royce antedated Karl Barth's insistence that the Church's fundamental posture is to be "herald." She is called to point to the Atoning Messiah, or in Roycean terms, to indicate the Great Interpreter sent from above to reconcile and form the Beloved Community. In Roman Catholic thought, Hans Kuhn's view of the Church is that of a "herald." (See A. Dulles, S.J., Models of the Church (New York: Doubleday, 1974), 72.)

${ }^{10}$ The Problem of Christianity, II, 386.

11 Ibid., 388. 
We have examined Royce's choice of the Baptizer's stance towards Christianity as an illustration of his authenticity to the religious interest within him. That interest-both personal and philosophical-now stands clear, as does the biographical context in which it was embodied. As one approaches Dr. Jarvis' present study, meeting a few general questions may assist the orientation. The following questions, then, aim to heighten interest, evoke a more critical search, and win a more balanced sifting of Royce's ideas. Dr. Jarvis and especially Josiah Royce deserve this much as we enter an examination of the latter's conception of God.

First, then, did the mature Royce's interpretation of evil shift significantly enough from that of his middle period to affect notably his final conception of God? Secondly, does Royce see an essentially religious function within that peculiar logical relation-the epsilon relation-whereby a finite self is united to the community as such? Finally, does the Roycean "eternal"- that "conscious and superhuman unity of life," 12 unlike the separated Platonic "eternal"-provide a basis for our a-temporal knowing of the truth of God's Actuality?

More important than such queries towards opening our minds to Dr. Jarvis' work, however, is a sympathetic grasp of Royce's personality. What was the spirit of the man? If we muse a bit over the symbols found in Josiah Royce's living room and study, we may grasp something of his spirit. There one would see a bust of Beethoven, a walking stick, heaps of books on ethics, logic, metaphysics, psychology, and history, along with a partly tattered overcoat-and all this immersed in a bluish fog of cigar smoke. These signs may well hint at the music-loving, often-hiking, voraciously reading, often ill-dressed, and incurably smoking personality of Josiah Royce. Yet they may veil rather than reveal his genius. For that genius went deeper. It was rooted in his great intellectual potential, in his passionate will for truth, and in his gradually refined appreciation of the many levels of human feelings. In some early essays he clearly articulated his self-identification as one who is a "will to truth" and who resonates with "our deepest human feelings." That will was often bold in the middle-period Royce, sometimes even brusk. It thus inhibited some of his growth in appreciation of other selves. But in his maturer years, that will, as transformed into a "loyal spirit of interpretation" became more humane and communal, more understanding

13 Josiah Royce, The Philosophy of Loyalty (New York: Macmillan, 1907), 357. 
and mellowed. Effecting this development was not so much his reduced physical powers, but especially his docility to the interpretative process. Hence, especially in Royce's maturer years, I find a wisdom. It radiated in many of his attitudes. He wanted his students and colleagues to dissent from his views for fuller truth. He preferred them to initiate still better fosterings of communities of interpretation. After his 1912 stroke, he trimmed his sails and bade farewell to his cherished project of a major work in logic. From 1914 to 1916, many Americans clung to an isolationist policy of non-involvement in World War I. Royce began sensing the unrealism of such a policy, faced up to the oneworldism of the major Western powers, and spoke out prophetically against our non-action which allowed one nation unilaterally to inflict its violent will upon others. In my estimate, Royce's 1908 threedimensional theory of truth shows far more wisdom than does James' simplistic sketch of a truth theory in Pragmatism. Then, too, wisdom fills Royce's insight that loyalty to any genuine community carries with it an openness to the divine. The phenomenology of moral ideals in his late ethics seems to reflect a similar wisdom. For paralleling his earlier natural dialectic of our four conceptions of Being, Royce now traced out a progressive series of moral ideals. The series passes by self-correction from the ideal of king-hero, through those of solitary saint and independent Titan, to that of a "suffering servant of mankind" who reconciles by atoning loyalty. This led Royce in his last course in ethics to examine our various forms of alienation and to indicate wise ways of healing and counterbalancing them by the appropriate forms of loyalty. Such facets, then, reflect something of the spirit of the wise "Socrates of Irving Street," Josiah Royce.

The Foreword and especially Dr. Jarvis' present work will both reach their mark if they aid the reader to assimilate some Roycean wisdom. Royce designedly formulated his wisdom "from the human side" only. For he significantly abstained from professing any divine wisdom whereby God may be specially schooling (and holding more responsible) some members of the human community.

Frank M. Oppenheim, S.J.

Xavier University,

Cincinnati, Ohio. 


\section{PREFACE}

This book has grown out of a doctoral thesis whose aim was to compare Royce's later conception of God with the conceptions of his early and middle periods in order to ascertain the extent of change in his later outlook. John E. Smith notes "the puzzle familiar to every student of Royce-exactly how is the later theory of interpretation related to Royce's initial philosophy of the Absolute?" ${ }^{1}$ Royce's early conception of God, as seen in The Religious Aspect of Philosophy, ${ }^{2}$ is characterized by a monistic formulation which appears to leave no room for the integrity and freedom of finite moral agents, as his contemporary critics claimed. The transition in Royce's thought from his early to his middle period, as seen in the Supplementary Essay of The Conception of God $^{3}$ and in The World and the Individual, ${ }^{4}$ is marked by vigorous efforts, particularly through a new emphasis upon "will" or purpose, to defend his concept of the Absolute from the former criticism. Royce's later conception of God in The Problem of Christianity ${ }^{5}$ was significantly influenced by the theories of community and of interpretation which he introduced at that time, the latter under the acknowledged influence of Charles S. Peirce.

The question how the later conception of God differs from those of the early and middle periods receives widely different answers from Royce's commentators. One group sees no significant difference, but simply a different way of stating, through the community of interpretation,

${ }^{1}$ John E. Smith, Royce's Social Infinite (New York: Conn.: Archon Books, 1969), p. xiv.

The Religious Aspect of Philosophy (Boston and New York: Houghton Mifflin and Co., 1885).

${ }^{3}$ The Conception of God (New York: Macmillan Co., 1897).

4 The World and the Individual (2 vols.; New York: Macmillan Co., 1899 and 1901).

5 The Problem of Christianity (2 vols.; New York: Macmillan Co., 1913). 
the same basic concept of the Absolute. Among these commentators are Jacob Loewenberg ${ }^{6}$ and Gabriel Marcel. ${ }^{7}$ Other commentators suspect a more significant difference, for example, G. Watts Cunningham ${ }^{8}$ and Peter Fuss." J. Harry Cotton sees a "formal consistency between the social Absolute of the middle period and the ultimate community of the later period," although there was a development in Royce's thought which consisted in "a growth in the direction of greater concreteness." 10 This was due to Royce's increasing interest in the importance of the individual.

A somewhat more detailed study of the question was made by Mary Whiton Calkins whose article, "The Foundations in Royce's Philosophy for Christian Theism," elicited a letter of gratitude and general approval from Royce. ${ }^{11}$ In her article, Mary Calkins aims to show that the doctrine of Royce is in essential harmony with that of Christian Theism. She sees a difference between Royce's earlier conception of the Absolute Self and the doctrine of the Beloved Community.

Unquestionably, Royce seems by certain statements to make the universal community equivalent to the Self of his earlier books ... Yet, in spite of expressions like these, I believe that Royce does not actually identify the Absolute Self with the Universal Community. ${ }^{12}$

Rather, she believes that Royce "distinguishes God as spirit, counsellor, or interpreter from the church in which he expresses himself and from the world which he interprets." 13

- Fugitive Essays, ed. with an Introduction by Jacob Loewenberg (Cambridge: Harvard University Press, 1920), p. 12.

" Gabriel Marcel, La Métaphysique de Royce (Paris: Aubier, collection "Philosophie de l'esprit," 1945). English translation, Royce's Methaphysics, trans. by Virginia and Gordon Ringer (Chicago: Henry Regnery Co., 1956), pp. 127, 129, and 147.

8 G. Watts Cunningham, The Idealistic Argument in Recent British and American Philosophy (New York and London: Appleton Century Co., 1933), p. 260.

- Peter Fuss, The Moral Philosophy of Josiah Royce (Cambridge: Harvard University Press, 1965), p. 259.

${ }^{10} \mathrm{~J}$. Harry Cotton, Royce on the Human Self (Cambridge: Harvard University Press, 1954), pp. 263 and 265.

" Mary Calkins, "The Foundations in Royce's Philosophy for Christian Theism," The Philosophical Review, XXV (1916), pp. 282-93. Extracts from Royce's letter follow the article. The entire letter is printed in The Letters of Josiah Royce, ed. with an introduction by John Clendenning (Chicago: University of Chicago Press, 1970), pp. 644-48.

12 Calkins, op. cit., p. 278.

13 Ibid., pp. 287-88. 
In his letter to Mary Calkins, Royce seems to approve generally both the idea of continuity and the idea of difference between the later conception of God and the earlier concept of the Absolute. Referring to The Problem of Christianity, Royce writes,

These reflections constitute for me, not something inconsistent with my former position, but a distinct addition to my former position, a new attainment,-I believe a new growth. I do not believe that you change in a way involving inconsistency when you reinterpret former ideas.

The Problem of Christianity ... is the product of what for me is a new light, of a new experience, of ideas which are as new to me as the original form of my idealism was new to me when I first defined it. ${ }^{14}$

These citations draw attention to the need for a detailed comparative study to try to determine more precisely the elements of continuity and difference between Royce's later conception of God and his earlier conceptions. This synthetic aim requires a careful genetic study in which each period of Royce's thought is analyzed to determine its precise mode of arguing to God's existence and the conception of God which it presents. At the close we will summarize what appear to be the central elements of continuity and the major points of difference. Besides this result, we hope that this genetic study of Royce's thought will provide a clear and helpful commentary to students who are being introduced to his works. Our main attention will be given to Royce's later work, The Problem of Christianity, with such attention to his earlier works as is needed to justly understand them and to trace the development of his thought.

In his unpublished "Augustus Graham Lectures," ${ }^{15}$ delivered in 1896, Royce provides helpful background for situating him historically and for understanding why he adopted the particular approach which he took to the question of God. Royce says that the view of Aristotle has been the prototype of all traditional theistic arguments for God's existence from first cause and from design. To Aristotle the existence of God was an hypothesis of natural science.

For Aristotle laws of nature were laws of a live organism, and of one whose life was in ... the ends for which it strove. Therefore, reasoned Aristotle, this end, this

14 The Philosophical Review, XXV (1916), p. 294.

${ }^{15}$ The "Augustus Graham Lectures" were delivered at the Brooklyn Institute between January 5 and March 1, 1896. This series of five lectures are concerned with the existence and nature of God and with his relation to the world. They are found at the Harvard University Archives (afterwards abbreviated, H.U.A.), Royce Manuscripts, Vols. 67 and 68. 
perfection, which is presupposed in order to give the world's life any meaning, must exist, and, as existent, is God, whose essence is his perfection. Towards him, as the ideal, nature everywhere aims and that is why his existence is needed to make nature intelligible. ${ }^{10}$

However, Aristotle's view of nature is not that taken by modern science, nor does Aristotle's theism flow from the pre-suppositions of modern science.

The existence of God is compatible with the tendency which natural science represents, but, on the other hand, it is, to my mind, a total misunderstanding of the historical relations as well as of theological implications when apologetic theologians view natural science as containing, or as capable of containing, any confirmation of traditional theism, especially any confirmations of the arguments from First Cause and from Design. For modern natural science grew up upon the basis of an emphatic opposition to Aristotle's whole conception of nature. And while one may still attempt to reconcile the two hostile views, it is vain to look for special help from either one of them in accomplishing the task. ${ }^{17}$

Aristotle's arguments suppose a world in which God is the giver of natural law, while modern science studies natural law without any necessary reference to God. A law is simply "a precise description of some process that repeatedly occurs in nature." 18

Royce distinguishes three modern tendencies in philosophy according as they interpret modern science in relation to the question of God. Royce calls the first, philosophical realism. Due to the influence of mechanics and to the success of the positive sciences, this philosophical tendency views the universe as an object whose conformity to allpervading law is a known or knowable truth,_-"a truth which, if you take the presuppositions of science as literal and philosophically true assertions, is independent of the human point of view." 19 The universe is a mechanism, rigidly controlled by law, in the presence of whose processes the traditional theism derived from Aristotle is no necessary hypothesis.

Opposed to this realism is the view of Kant which says that Reality is unknowable; natural law exists only for the human point of view. Our intellect is powerless to see through the perspective of our experience to any theoretically clear knowledge of reality. "Kant was a theist who regarded his own theoretical agnosticism as actually a means for

${ }_{16}$ Op. cit., vol. 67, Lecture I, "The Present Position of Theism," pp. 43-44.

17 Ibid., pp. 45-56.

${ }^{18}$ Op. cit., vol. 68, Lecture IV, "God and Nature; Evolution and Ethics," p. 15.

10 Op. cit., vol. 67, Lecture I, "The Present Position of Theism," p. 48. 
establishing the necessity of what he called a strictly rational faith in God." 20 This was a faith in the supremacy of righteousness in the universe. "And this supremacy means, for Kant, the sovereignty of a righteous God." 21

Post-Kantian Idealism is a third modern tendency which, historically speaking, is an outgrowth from Kant's own philosophy, but it reads the lesson of Kant not as he himself did. It agrees with Kant that nature as our human sciences view nature is an appearance, a collection of mere phenomena whose deepest basis no mechanical science can reveal. But it disagrees with Kant's assertion that there is no way to a comprehension, in general terms, of the true nature of Reality. Unable though we are to get more than such a general notion of the nature of Reality, Idealism holds that we can attain a positive if incomplete knowledge of the Reality. ${ }^{22}$

Idealism has founded its positive theses upon the very basis which Kant's Agnosticism has laid. Fully recognizing that the world which natural science knows is a world of mere phenomena, Idealism has gone on to maintain a theory as to the Absolute Spirit. $^{23}$

Common to the various forms of modern idealism is the effort "to define the Absolute in spiritual terms, and to insist upon the unity of its life as analogous to the unity which we observe in our own inner life." 24 Beyond this point modern idealists have widely diverged.

Royce is without doubt indebted to the tradition of modern idealism to which he remained loyal to the end of his life. But his own expression was unique in various ways, and it evolved partly under the early influence of William James and, later and more significantly, under the influence of Charles S. Peirce. His studies in mathematics became an increasing source of philosophical inspiration, while extensive work in psychology kept his expressions of idealism well-anchored empirically. The active nature of ideas and the questions, What is truth? and How is it attained? formed a permanent part of his approach to reality.

I wish to acknowledge my debt in writing this book to many who have helped me, and especially to the insightful suggestions and unfailing encouragement of Dr. Donald A. Gallagher who directed my dissertation, and to the Faculty of Philosophy of the University of Ottawa who supervised it. I also thank Rev. Frank M. Oppenheim, S.J. who has provided me with invaluable scholarly criticisms in regard to my approach

\footnotetext{
${ }^{20}$ Ibid., p. 56.

${ }^{21}$ Ibid., p. 58 .

${ }^{22}$ Ibid., p. 60 .

23 Ibid., p. 67.

${ }^{24}$ Ibid., p. 64.
} 
to Royce, and I am grateful for the assistance of the Peirce scholar, Dr. Matthew J. Fairbanks. I wish to thank Harvard University Archives for its courtesy in providing me leisurely access to its collection of unpublished Royce manuscripts.

Edward A. Jarvis, S.J.

University of Scranton, Pa.

August 1974 